\title{
Merkel Cell Carcinoma pN1 TNM Finding v7
}

National Cancer Institute

\section{Source}

National Cancer Institute. Merkel Cell Carcinoma pN1 TNM Finding v7. NCI Thesaurus.

Code C88528.

Merkel cell carcinoma with metastasis in regional lymph node(s). (from AJCC 7th Ed.) 